\title{
Vascular interactions of Croton schiedeanus major flavonoids in isolated aortic rings from Wistar rats
}

\author{
Interacciones vasculares de los principales flavonoides \\ de Croton schiedeanus en anillos aislados de aorta \\ de ratas Wistar
}

Alejandra Paola ORTIZ ${ }^{\circledR}$, Pilar PUEBLA², Mario Francisco GUERRERO³

JOURNAL VITAE

School of Pharmaceutical and Food Sciences

ISSN 0121-4004 | ISSNe 2145-2660

University of Antioquia Medellin, Colombia

Filliations

${ }^{1}$ MSc Pharmacology. Department of Pharmacy, Faculty of Sciences, "Universidad Nacional de Colombia",

111321, Bogotá D.C., Colombia.

${ }^{2}$ PhD/Professor. Department of Pharmaceutical Sciences, Faculty of Pharmacy, Universidad de Salamanca, 37007, Salamanca, Spain.

${ }^{3} \mathrm{PhD} /$ Professor. Department of Pharmacy, Faculty of Sciences, "Universidad Nacional de Colombia", 111321, Bogotá D.C., Colombia.

\section{*Corresponding Mario Francisco GUERRERO mfguerrerop@unal.edu.co}

Received: 28 September 2020 Accepted: 16 April 2021 Published: 17 May 2021

\begin{abstract}
Background: Ayanin (3,7,4'-Tri-O-methylquercetin) and 3,7-Di-O-methylquercetin (DMQ) are the main active metabolites isolated by bioguided fractionation from Croton schiedeanus, species known popularly in Colombia as "almizclillo", which has been studied in experimental models in rats, exerting vasodilator and antihypertensive effects. Also, when the effect of these flavonoids was studied separately, important vasodilation was observed. Objective: To evaluate whether flavonoids from Croton schiedeanus have synergistic vasodilator properties when different combinations are used in isolated aorta rings. Methods: Cumulative concentrations of ayanin $\left(10^{-8} \mathrm{M}-6 \times 10^{-5} \mathrm{M}\right.$ or $\left.0.01 \mu \mathrm{M}-60 \mu \mathrm{M}\right)$ were assayed in the absence and presence of an increasing concentration of 3,7-Di-O-methylquercetin (DMQ) $\left(10^{-8}-3 \times 10^{-5}\right.$ $\mathrm{M}$ or $0.01-30 \mu \mathrm{M}$ ) in isolated rings from Wistar rats, pre-contracted with phenylephrine. The concentration-response curve with the maximal effect was compared with that obtained by Croton schiedeanus whole ethanolic extract $\left(10^{-6}-3 \times 10^{-4} \mathrm{~g} / \mathrm{mL}\right)$. Also, this combination was assayed in the presence of the nitric oxide synthetase inhibitor L-NAME $\left(10^{-4} \mathrm{M}\right)$ and the guanylate cyclase inhibitor methylene blue $\left(10^{-4} \mathrm{M}\right)$ to assess the role of the NO/cGMP pathway in this interaction. Results: Ayanin and DMQ display a dual interaction in vascular relaxant response: agonism at higher concentration ranges $\left(10^{-6}-3 \times 10^{-5} \mathrm{M}\right.$ or $\left.1-30 \mu \mathrm{M}\right)$ and antagonism at lower concentration ranges $\left(10^{-8}-3 \times 10^{-7} \mathrm{M}\right.$ or $\left.0.01-0.3 \mu \mathrm{M}\right)$. The efficacy at the highest concentration was greater than that obtained by the whole extract $\left(E_{\max }: 98.4 \%\right.$ vs. $33.9 \%$ ). This response was decreased but not reverted in the presence of L-NAME and methylene blue. Thus, the vasodilator effect of this combination does not depend entirely on the NO/cGMP cyclic pathway. Conclusion: The combined use of appropriate concentrations of these flavonoids could represent an advantage over Croton schiedeanus whole extract for vasodilator purposes.
\end{abstract}

Keywords: Ayanin, Flavonoid, Nitric oxide, Guanylate cyclase, Synergism, Croton. 


\section{RESUMEN}

Antecedentes: Ayanina (3,7,4'-Tri-O-metilquercetina) y 3,7-Di-O-metilquercetina (DMQ) son los principales metabolitos activos aislados mediante fraccionamiento bioguiado, a partir de Croton schiedeanus, especie conocida popularmente en Colombia como "almizclillo", la cual ha sido estudiada en modelos experimentales en ratas, ejerciendo efectos antihipertensivos y vasodilatadores. Además, al estudiar por separado el efecto de los flavonoides, se observó importante vasodilatación. Objetivo: Evaluar si los principales flavonoides de Croton schiedeanus tienen propiedades vasodilatadoras sinérgicas al utilizar diferentes combinaciones de ellos en anillos de aorta aislados. Metodología: Se analizaron concentraciones acumulativas de ayanina $\left(10^{-8} \mathrm{M}-6 \times 10^{-5} \mathrm{M} \circ 0,01 \mu \mathrm{M}-60 \mu \mathrm{M}\right)$ en ausencia y en presencia de concentraciones crecientes de $\mathrm{DMO}\left(10^{-8} \mathrm{M}-3 \times 10^{-5} \mathrm{M}\right.$ o $0,01 \mu \mathrm{M}-30 \mu \mathrm{M})$ en anillos aislados de ratas Wistar, pre-contraídos con fenilefrina. La curva concentración respuesta obtenida con el efecto máximo, fue comparada con la obtenida con el extracto etanólico de Croton schiedeanus $\left(10^{-6}-3 \times 10^{-4} \mathrm{~g} / \mathrm{mL}\right)$. Adicionalmente, esta combinación fue ensayada en presencia del inhibidor de óxido nítrico sintetasa L-NAME (10-4 M) y el inhibidor de guanilato ciclasa, azul de metileno $\left(10^{-4} \mathrm{M}\right)$ para evaluar el papel de la vía NO/GMPc en esta interacción. Resultados: Ayanina y DMQ muestran una interacción dual en la respuesta vascular relajante: agonismo en el rango más alto $\left(10^{-6} \mathrm{M}-3 \times 10^{-5} \mathrm{M}\right.$ o $1 \mu \mathrm{M}-30 \mu \mathrm{M})$, y antagonismo en el rango más bajo $\left(10^{-8} \mathrm{M}-3 \times 10^{-7} \mathrm{M} \circ 0.01 \mu \mathrm{M}-0,3 \mu \mathrm{M}\right)$. A altas concentraciones, la eficacia de los flavonoides fue mayor que las obtenidas por el extracto completo ( $E_{\text {máx: }}: 98,4 \%$ vs 33,9\%). Esta respuesta disminuyó, pero no se revirtió en presencia de L-NAME y azul de metileno. Por lo tanto, el efecto vasodilatador de esta combinación no depende enteramente de la vía NO/GMPc. Conclusión: El uso combinado de las concentraciones apropiadas de estos flavonoides podría representar una ventaja sobre el extracto de Croton schiedeanus, con propósitos vasodilatadores.

Palabras clave: Ayanina, Flavonoide, Óxido nítrico, Guanilato ciclasa, Sinergismo, Croton.

\section{INTRODUCTION}

Hypertension is one of the most critical factors related to cardiovascular disorders, such as coronary heart disease, cardiac arrhythmias, stroke, and kidney failure, among others (1). According to the World Health Organization (WHO), between 20\% and $35 \%$ of the adult population from Latin America and the Caribbean are affected by hypertension (2). There are many pharmacological alternatives for the effective treatment of hypertension. The selection of adequate drugs is based on the efficacy to decrease blood pressure and cardiovascular risk, including strokes and heart failure (3), but this all depends on the safety profile of each treatment and patient. The management requires chronic use, usually with more than one drug simultaneously, so many adverse effects can appear, such as sedation, disorders of mental concentration, hypotension, acute kidney failure, hypercalcemia, dry cough, angioedema, etc. (4), which can affect the treatment adherence. Alternatively, despite the efficacy of existing treatments, there are low control rates because one in three people with hypertension cannot keep their blood pressure below 140/90 (5).

The interest in combined therapy has increased, intending to improve the efficacy and security of antihypertensive treatments (6). There are combinations in hypertension that have a better profile than monotherapy, which can be used according to the patient's cardiovascular risk and are almost essential for reaching therapeutic goals. Nevertheless, not all combinations are beneficial. The guidelines recommend combining those that act by different mechanisms, for example, ACE inhibitors (angiotensin-converting enzyme inhibitors) or ARB (angiotensin receptor blockers), plus one diuretic or a calcium antagonist, while another option is using a thiazide diuretic plus a potassiumsparing diuretic (7).

Combined treatments have taken importance in recent years to achieve greater efficacy and treatment adherence, intended to keep blood pressure under control (6). Phytotherapeutics could contribute to the perspective of a combination approach, given its multicomponent nature. Bioguided fractionation increases the probability of finding additive, synergistic or antagonistic interactions between metabolites (8). The multicomponent nature of medicinal plants can be especially appropriate to treat complex diseases when their key metabolites display synergistic effects through different mechanisms.

The appropriate combination of natural metabolites could represent a therapeutic approach in searching for new alternatives to treat hypertension, with a good efficacy profile and safety (9). Among others, phenolic compounds, especially flavonoids (10), are associated with cardiovascular disease prevention (11), and mortality reduction (12). Studies involving flavonoid consumption have demonstrated arterial pressure decrement and improvement of endothelial dysfunction (13). Moreover, the vasodilator property of these compounds is associated with the regulated bioavailability of $\mathrm{NO}$ through the induction of nitric oxide synthetase (NOS), and the inhibition of nitric oxidation (14). Most of the studies showing the cardioprotective effects of flavonoids have been 
more focused on flavones (15), a group to which the compounds of interest in this work belong.

Croton schiedeanus is one of the medicinal plants that is popularly used in Colombia for hypertension. It is a member of the Euphorbiaceae family, which includes about 1300 species, several of which are traditionally used as medicinal plants in Africa, Asia, and America $(16,17)$. Its leaves are used in infusions, and its common name in Colombia is "almizclillo" (18), while in other countries, such as Mexico and Costa Rica, it is called "copalchí" $(19,20)$ or "corpachí", and "sanrillo de pasto" in Panama (21).

Previous assays using experimental models of hypertension in rats have shown that the ethanolic extract of this plant exerts antihypertensive activity while decreasing arterial pressure and cardiac frequency (22) and relaxing vascular tone (23). Phytochemical studies of this species have led to the isolation and identification of 3,7-Di$O$-methylquercetin, the most potent, and ayanin, the most abundant, among others (24) (25). Nevertheless, possible interactions between these flavonoids have not been elucidated to date.

The interest in finding any interactions between these compounds is focused on the benefits of the possible synergism because it could reduce the number of substances needed to elicit the desired vasodilator effect (26). Pharmacological synergism can occur by different mechanisms, like regulating enzymes and transporters involved in hepatic and intestinal metabolism, improving bioavailability, and increasing potency, etc. Finding active metabolites with synergistic mechanisms could allow discovering new phytopharmaceutical alternatives of treatment (27).

Synergism is a potential advantage of plants because the combination or mixture of compounds leads to a greater collective response than the obtained using each isolated compound (28). For many years, the interest in identifying and quantifying synergism has increased due to the benefits that this type of interaction provides, as described above. Empirical methods have been used, along with mathematical models, including the Loewe $(29,30)$, Bliss, and HSA (highest individual agent) models, and Chou-Talalay as a classical reference (31).

The purposes of this research focused on assessing whether different combinations of the principal metabolites of Croton schiedeanus could exert synergism and therefore improve the vasorelaxant effect obtained from the whole extract.

\section{METHODS AND MATERIALS}

\subsection{Chemicals}

DMO (3,7-Di-O-methylquercetin) and ayanin (3,7,4'-Tri-O-methylquercetin) were isolated from Croton schiedeanus, according to the detailed procedure described elsewhere (32). The aerial parts of the plant were collected from Tocaima, Cundinamarca, Colombia, and identified at the Herbarium of the Natural Sciences Institute of the National University of Colombia (voucher number: 432164). DMO and ayanin m.p., ${ }^{1} \mathrm{H}$ - and ${ }^{13} \mathrm{C}-\mathrm{NMR}$ spectra were identical to the previously reported results (33). The whole ethanolic extract was obtained from the leaves of the vegetal material that was dried and soaked in $96 \% \mathrm{EtOH}$, and the solvent was removed under vacuum (32).

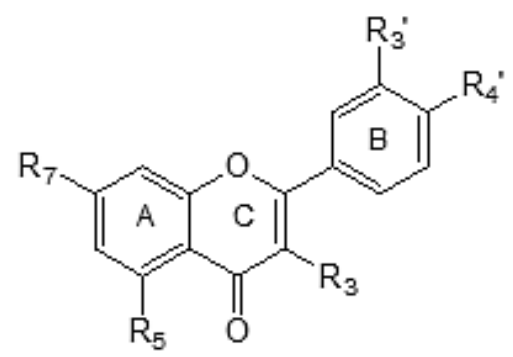

\begin{tabular}{lccccc}
\hline \multicolumn{1}{c}{ Compound } & $\mathbf{R}_{\mathbf{3}}$ & $\mathbf{R}_{\mathbf{5}}$ & $\mathbf{R}_{\mathbf{7}}$ & $\mathbf{R}_{\mathbf{3}}^{\prime}$ & $\mathbf{R}_{\mathbf{4}}^{-}$ \\
\hline 3,7-Di-O-methylquercetin (MO) & $\mathrm{OMe}$ & $\mathrm{OH}$ & $\mathrm{OMe}$ & $\mathrm{OH}$ & $\mathrm{OH}$ \\
$\begin{array}{l}\text { 3,7,4'-Tri-O-methylquercetin } \\
\text { (ayanin) }\end{array}$ & $\mathrm{OMe}$ & $\mathrm{OH}$ & $\mathrm{OMe}$ & $\mathrm{OH}$ & $\mathrm{OMe}$ \\
\hline
\end{tabular}

Figure 1. Chemical structure of DMQ and ayanin. Adapted from Guerrero et al. 2002 (32).

\subsection{Animals: maintenance and treatment}

Forty-four males and females Wistar rats were provided by the Pharmacy Department Bioterium at the National University of Colombia and maintained under light/darkness (12 $\mathrm{h}$ each period), with free access to food and water, except for $12 \mathrm{~h}$ before each experiment. Animals were euthanized by $\mathrm{CO}_{2}$ anesthesia prior to the aortic resection. The Bioethics Committee of the Faculty of Sciences of the National University of Colombia approved this work (Act 02-2018).

\subsubsection{Isolated bath aortic ring preparation}

The aorta free of fat and adjacent connective tissue was placed in a Petri dish with a paraffin floor, immersed in Krebs solution, and oxygenated with carbogen $\left(\mathrm{O}_{2} 95 \%\right.$ and $\left.\mathrm{CO}_{2} 5 \%\right)$. The artery 
was cut into rings of $4-5 \mathrm{~mm}$ and placed each in a bath containing $15 \mathrm{~mL}$ of Krebs solution at $37^{\circ} \mathrm{C}$ and $\mathrm{pH} 7.4$, gasified with carbogen. Krebs solution composition was the following: sodium chloride $(\mathrm{NaCl}) 118.0 \mathrm{mM}$, potassium chloride (KCl) $4.75 \mathrm{mM}$, calcium chloride $\left(\mathrm{CaCl}_{2}\right) 1.8 \mathrm{mM}$, magnesium sulfate $\left(\mathrm{MgSO}_{4}\right) 1.2 \mathrm{mM}$, potassium dihydrogen phosphate $\left(\mathrm{KH}_{2} \mathrm{PO}_{4}\right) 1.2 \mathrm{mM}$, sodium bicarbonate $\left(\mathrm{NaHCO}_{3}\right) 25$ $\mathrm{mM}$, glucose $11 \mathrm{mM}$ and ascorbic acid $0.1 \mathrm{mM}$ (34). Basal tension was adjusted to $2.000 \mathrm{mg}$, changing the physiological solution every 15 minutes until the stabilization of ring tone, when phenylephrine was added $\left(10^{-6} \mathrm{M}\right)$ to attain maximal plateau contraction. Treatments were added according to the following protocols:

\subsubsection{Ayanin and DMO vascular interactions}

Once the maximum tension was reached after the addition of phenylephrine $\left(10^{-6} \mathrm{M}\right)$, ayanin was added in cumulative concentrations $\left(10^{-8}, 3 \times 10^{-8}, 10^{-7}, 3 \times 10^{-}\right.$ $7,10^{-6}, 3 \times 10^{-6}, 10^{-5}, 3 \times 10^{-5}$, and $6 \times 10^{-5} \mathrm{M}$ or $0.01,0.03$, $0.1,0.3,1,3,10,30$, and $60 \mu \mathrm{M})$ in the absence and presence of $\mathrm{DMQ}$ at the following concentrations: $10^{-8}, 3 \times 10^{-8}, 10^{-7}, 3 \times 10^{-7}, 10^{-6}, 3 \times 10^{-6}, 10^{-5}$ and $3 \times 10^{-5}$ M. DMQ was added almost simultaneously to the bath as ayanin. In some rings, dimethyl sulfoxide at $0.1 \%$ (DMSO) was added as a control.

\subsubsection{Croton schiedeanus extract assay}

Once the maximum tension was reached with phenylephrine $\left(10^{-6} \mathrm{M}\right)$, Croton schiedeanus ethanolic extract was added to cumulative concentrations $\left(10^{-6}\right.$, $10^{-5}, 3 \times 10^{-5}, 10^{-4}$, and $3 \times 10^{-4} \mathrm{~g} / \mathrm{mL}$ ). This response was compared to that obtained with ayanin $\left(3 \times 10^{-10}\right.$, $3 \times 10^{-9}, 10^{-8}, 3 \times 10^{-8}, 10^{-7}, 3 \times 10^{-7}, 10^{-6}, 3 \times 10^{-6}$ and $10^{-5}$ $\mathrm{g} / \mathrm{mL})$, DMQ $\left(3 \times 10^{-10}-3 \times 10^{-6} \mathrm{~g} / \mathrm{mL}\right)$ and finally, with the combination ayanin plus DMQ $3 \times 10^{-6} \mathrm{~g} / \mathrm{mL}$. In some rings, dimethyl sulfoxide at $0.1 \%$ (DMSO) was added as a control.

\subsubsection{NO/cGMP pathway inhibition study}

To assess the role of the nitric oxide/cyclic guanosine monophosphate (NO/cGMP) pathway in the vascular interactions between ayanin and $\mathrm{DMQ}$, the nitric oxide synthetase inhibitor $N(\omega)$-nitro-L-arginine methyl ester (L-NAME) $\left(10^{-4} \mathrm{M}\right)$ or the guanylate cyclase inhibitor methylene blue $\left(10^{-4} \mathrm{M}\right)$ was added 15 min before the cumulative addition of ayanin in the presence of DMQ $\left(3 \times 10^{-5} \mathrm{M}\right)$, in rings precontracted with phenylephrine $\left(10^{-6} \mathrm{M}\right)$. In some rings, dimethyl sulfoxide at $0.1 \%$ (DMSO) was added as a control.

\subsubsection{Synergism studies}

The Loewe method $(29,30)$ and the mass action law (35) were used to assess whether vascular interactions between the combinations of ayanin and DMO were additive, synergistic, or antagonistic. We also used the Combenefit $(36,37)$ and CompuSyn packages (38). The CompuSyn combination index (Cl) was as follows: $<1$ means synergic, $>1$ means antagonism, and 1 indicates additivity; and Combenefit score $>0 \%$ means synergism, $<0$ denotes antagonism and equal to 0 indicates additivity $(35,38)$.

\subsubsection{Data analysis and statistics}

The vascular response was expressed as concentration-response curves showing the relaxation percentage obtained against rings pre-contracted with phenylephrine $\left(10^{-6} \mathrm{M}\right)$. Data were normalized according to the maximal relaxation attained when $\mathrm{DMQ}$ was added to ayanin. Contractions generated by the tension transducer were obtained using Data Trax 2 (WPI) software. All results were expressed as standard errors of the mean (S.E.M.). A sample of $n \geq 4$ was used for each treatment. Sigmoid curve fitting was performed to obtain inhibitory concentration $50\left(\mathrm{IC}_{50}\right)$ values and $p$ values $\left(-\log \mid \mathrm{C}_{50}\right)$.

Concentration-response curves were analyzed by two-way analysis of variance (ANOVA) followed by the Tukey post hoc analysis with a p-value of $\leq$ 0.05 . Exce ${ }^{\circledR}-16$ and GraphPad-Prism- $6^{\circledR}$ were used for data analysis.

\section{RESULTS}

\subsection{Ayanin and DMQ relaxant interactions}

Concentration-response curves of vasorelaxation were determined after being induced by ayanin in Wistar rat aortic rings, previously contracted with phenylephrine $\left(10^{-6} \mathrm{M}\right)$, in cumulative concentrations of ayanin $\left(10^{-8}-6 \times 10^{-5} \mathrm{M}\right.$ or $\left.0.01-60 \mu \mathrm{M}\right)$, in presence and absence of 3,7-Di-O-methylecrecetin (DMQ) $\left(10^{-8}-3 \times 10^{-5} \mathrm{M}\right.$ or $\left.0.01-30 \mu \mathrm{M}\right)$ (Figures 2 and 3 ). 


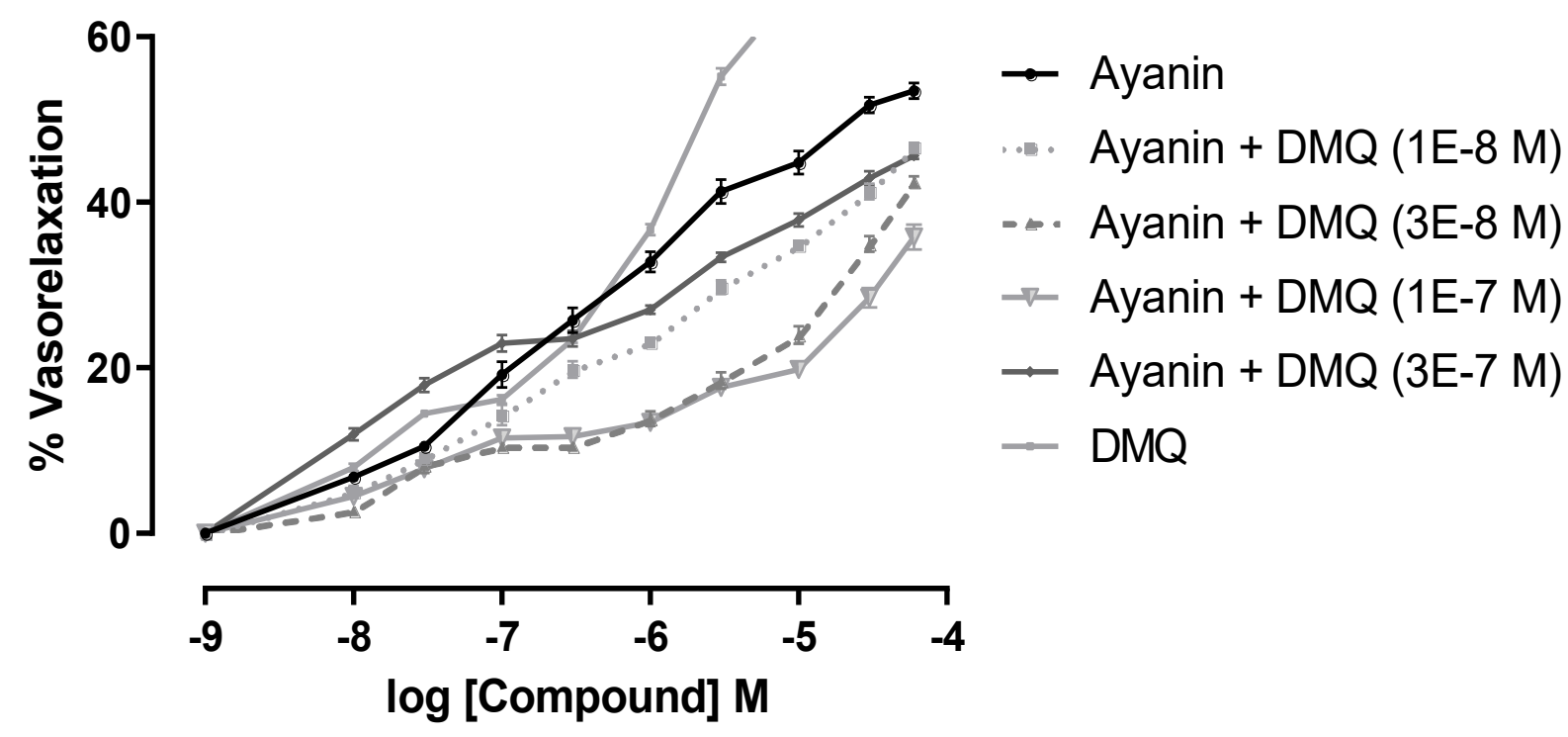

Figure 2. Decrease of the vasorelaxant effect of ayanin in presence of $3,7-\mathrm{Di}-\mathrm{O}$-methylquercetin (DMO) $\left(10^{-8}, 3 \times 10^{-8}, 10^{-7}\right.$ and $3 \times 10^{-7}$ $\mathrm{M})$, in rat aortic rings pre-contracted with phenylephrine $\left(10^{-6} \mathrm{M}\right)$. Each point represents the S.E.M.

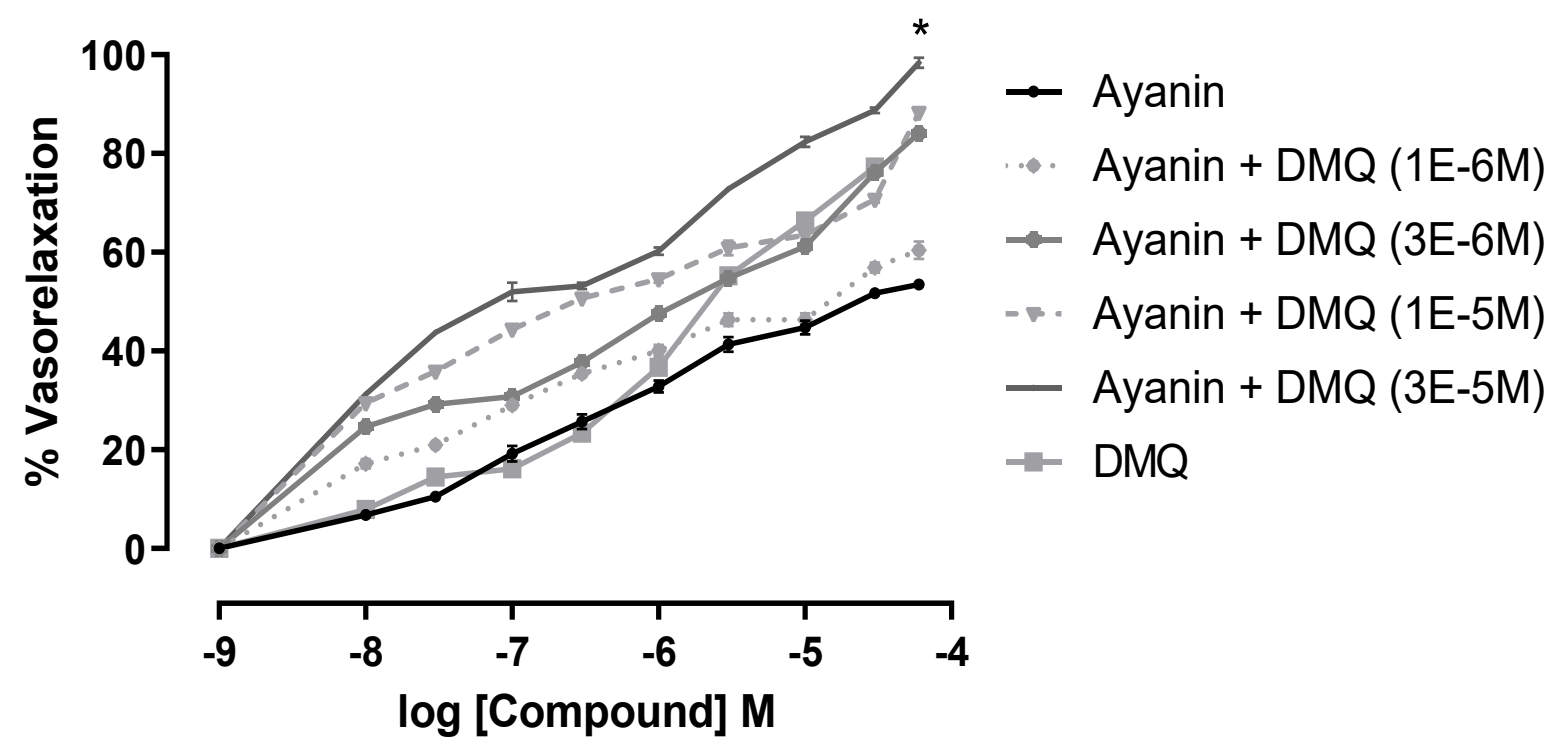

Figure 3. Increase of the vasorelaxant effect of ayanin in presence of 3,7-Di-O-methylquercetin (DMQ) of DMQ $\left(10^{-6}, 3 \times 10^{-6}, 10^{-5}\right.$ and $\left.3 \times 10^{-5} \mathrm{M}\right)$, in rat aortic rings pre-contracted with phenylephrine $\left(10^{-6} \mathrm{M}\right)$. Each point represents the S.E.M., ${ }^{*} \mathrm{p}<0.05$.

Fig. 2 shows that when $\mathrm{DMO}$ is added at concentrations of $10^{-8}-3 \times 10^{-7} \mathrm{M}$, the relaxant effect of ayanin decreased. Alternatively, Fig. 3 shows that the higher concentrations of DMQ evaluated $\left(10^{-6}-3 \times 10^{-5} \mathrm{M}\right)$ increased the effect of ayanin, exerting a dual effect, which was concentration-dependent. Furthermore, the highest concentration of DMO evaluated $\left(3 \times 10^{-5}\right.$ $\mathrm{M}$ or $30 \mu \mathrm{M}$ ) caused a significant increase in the response of ayanin $(p<0.001)$, which was about $50.5 \%$ of the maximum effect $\left(E_{\max }\right)$.

\subsection{Studies with the ethanolic extract}

The ethanolic extract of Croton schiedeanus had a vasorelaxant effect depending on the concentration, reaching total relaxation with an $\mathrm{E}_{\max } 33.9 \pm 3.1 \%$ in aortic rings pre-contracted with phenylephrine $\left(10^{-6}\right.$ M) and that effect was lower that the obtained with ayanin and DMQ using them separately as well as the combination of ayanin plus DMQ at $3 \times 10^{-5} \mathrm{M}$ (Figure 4). 


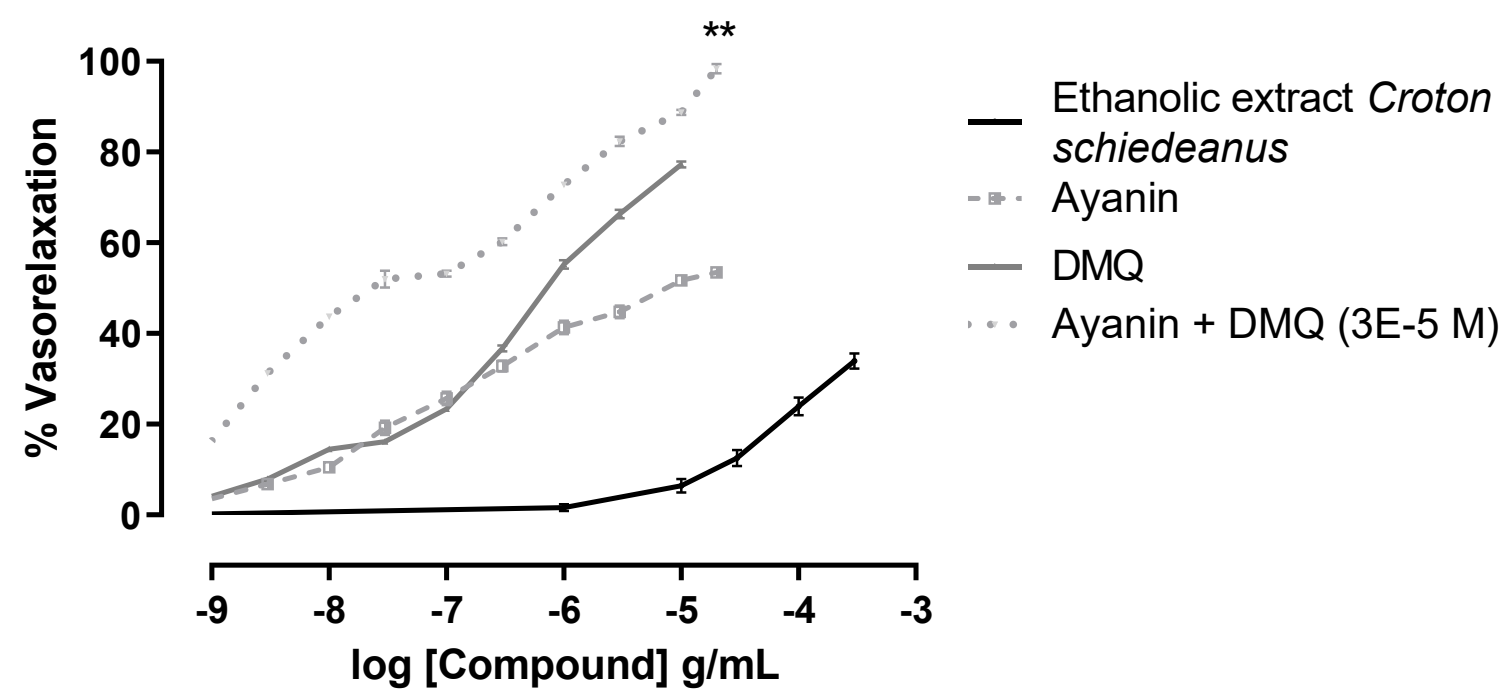

Figure 4. Concentration-response curves $\left(3 \times 10^{-10}-10^{-5} \mathrm{~g} / \mathrm{mL}\right)$ of vasorelaxant effect obtained with ayanin, DMQ $\left(3 \times 10^{-10}-10^{-6} \mathrm{~g} / \mathrm{mL}\right)$, ayanin plus DMQ $3 \times 10^{-5} \mathrm{M}\left(3 \times 10^{-6} \mathrm{~g} / \mathrm{mL}\right)$, and Croton schiedeanus whole ethanolic extract in rat aortic rings pre-contracted with phenylephrine $\left(10^{-6} \mathrm{M}\right)$. Each point represents the S. E. M., ${ }^{\star *} \mathrm{p}<0.01$.

On the other hand, ayanin caused a relaxant response with $\mathrm{E}_{\max } 53.5 \pm 1.7 \%$. The effect of $\mathrm{DMO}$ was higher than that of ayanin and extract, with $\mathrm{E}_{\max }$ $77.3 \pm 1.6 \%$.

The results in Fig. 3 and Fig. 4 show the concentrationresponse curves for ayanin determined in the presence and absence of DMQ; these results show that the higher concentration of DMQ evaluated $\left(3 \times 10^{-5} \mathrm{M}\right.$ or $\left.30 \mu \mathrm{M}\right)$ exerted the highest relaxation. The mentioned concentration was evaluated in the presence of the inhibitor of nitric oxide, L-NAME, and the inhibitor of guanylate cyclase, methylene blue, added when the maximum vasoconstriction was reached with phenylephrine. As a result, the total response was partially reduced (Fig. 5).

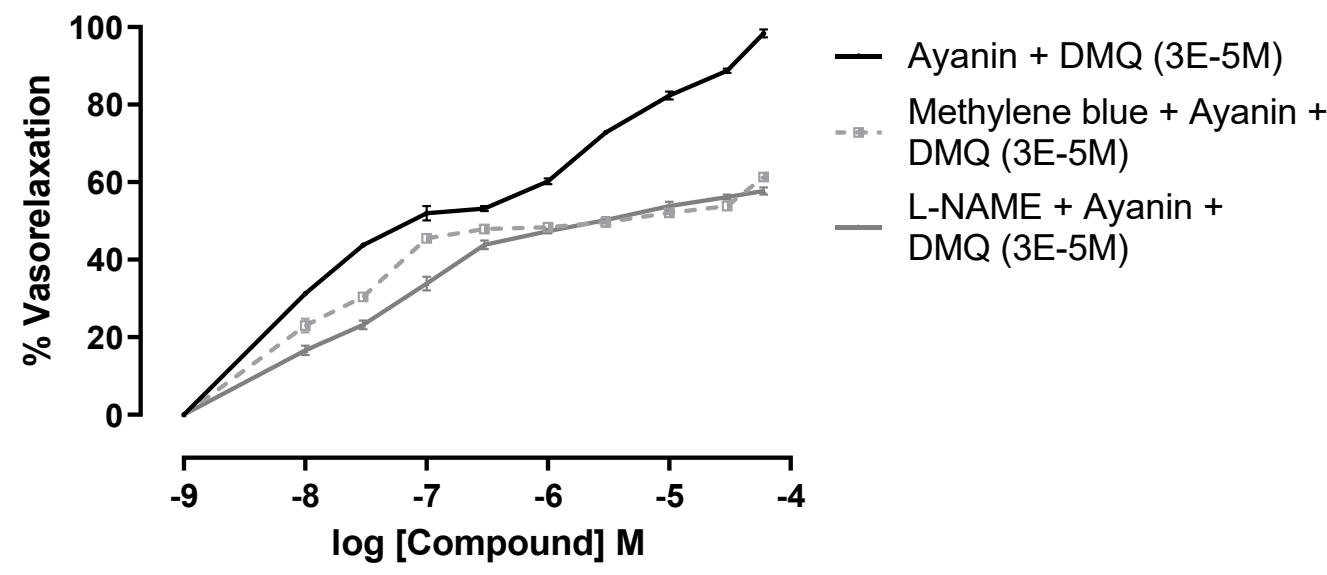

Figure 5. Concentration-response curves of ayanin vasorelaxant effect in presence of $\mathrm{DMQ}\left(3 \times 10^{-5} \mathrm{M}\right)$, in rat aortic rings pre-contracted with phenylephrine $\left(10^{-6} \mathrm{M}\right)$ and exposed to L-NAME $\left(10^{-4} \mathrm{M}\right)$ and methylene blue $\left(10^{-4} \mathrm{M}\right)$. Each point represents the mean S. E. M.

\subsubsection{Study of the interactions between ayanin and DMO}

The Loewe model used to assess the interactions between ayanin and DMO demonstrated a concentration dependent dual effect, synergism, and antagonism, based on the percentage of synergism. Figs. 6 and 7 show that effect, an increase in the synergism and a decrease of it, depending on the concentration of DMQ and ayanin when are added to the organ bath. 


\section{Loewe synergy and antagonism}

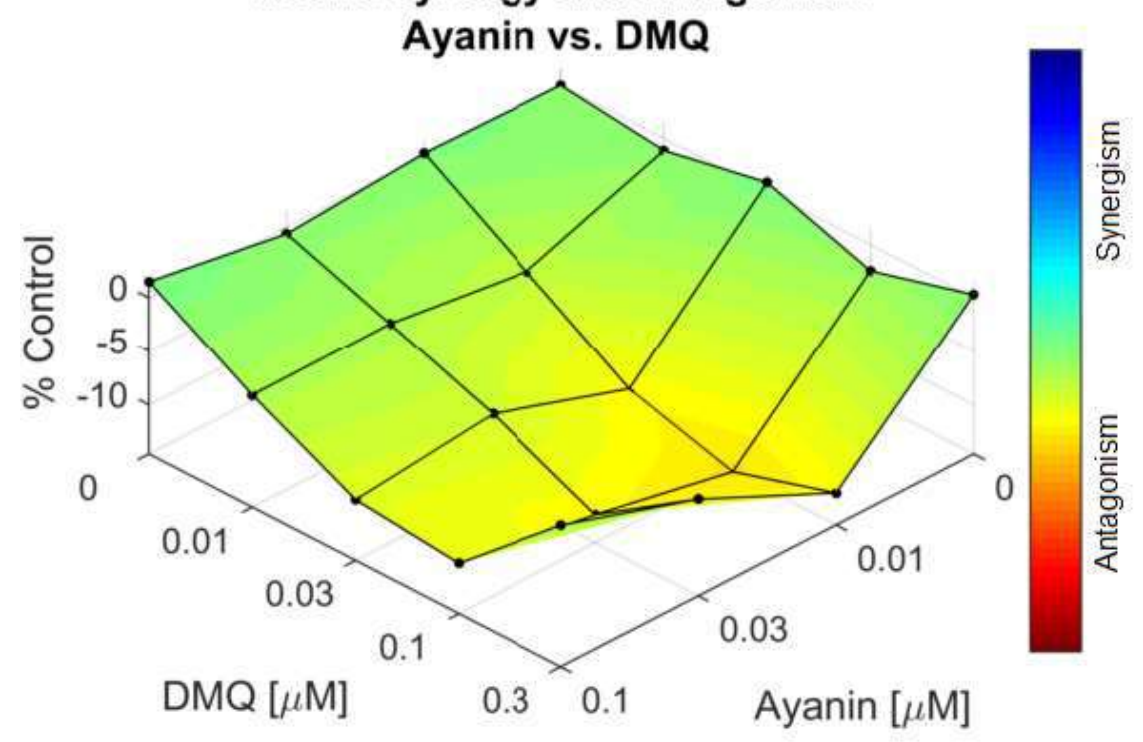

Figure 6. Surface map generated by Combenefit using the Loewe model. Represents the percentage of synergism between ayanin $\left(10^{-8}-10^{-7} \mathrm{M}\right.$ or $\left.0.01-0.1 \mu \mathrm{M}\right)$ and DMQ $\left(10^{-8}-3 \times 10^{-7} \mathrm{M}\right.$ or $\left.0.01-0.3 \mu \mathrm{M}\right)$.

\section{Loewe synergy and antagonism Ayanin vs. DMQ}

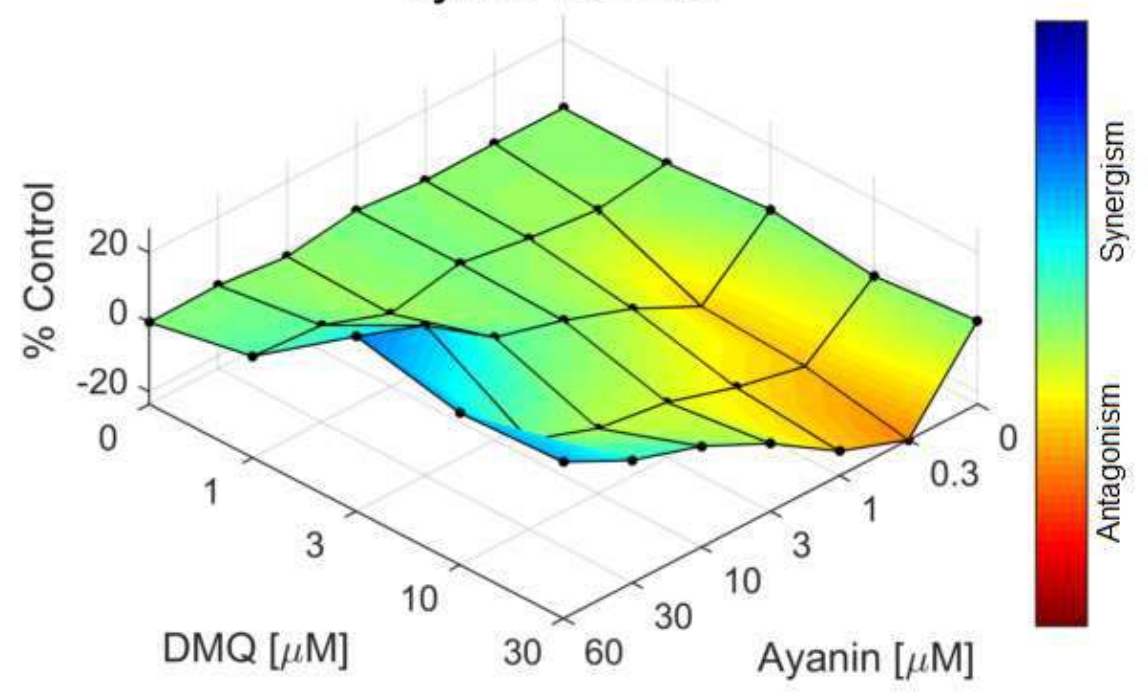

Figure 7. Surface map generated by Combenefit using the Loewe model. Represents the percentage of synergism between ayanin $\left(3 \times 10^{-7}-6 \times 10^{-5} \mathrm{M}\right.$ or $\left.0.3-60 \mu \mathrm{M}\right)$ and DMQ $\left(10^{-6}-3 \times 10^{-5} \mathrm{M}\right.$ or $\left.1-30 \mu \mathrm{M}\right)$.

These third-dimension graphs (Figures 6 and 7) show the percentage of synergism with different combinations of ayanin plus $\mathrm{DMQ}$; blue represents the concentrations that generate synergism, while orange or yellow indicates the antagonistic concentrations. Each point represents the effective concentration $50\left(E_{50}\right)$ of the different combinations of ayanin and DMQ, whose height above zero in the third dimension indicates synergism. Similarly, if the points are located on the plane or zero synergy percentage, there is additivity or $0 \%$ synergism.

Alternatively, the CompuSyn platform was also used, which constructed an isobologram (Fig. 8). Here, as in the surface map from Combenefit, each point represents the $\mathrm{EC}_{50}$ of the different combinations of ayanin plus DMQ. Points located under the slope indicate synergistic combinations; points located above the slope show antagonistic combinations; points on the slope show additive combinations. 


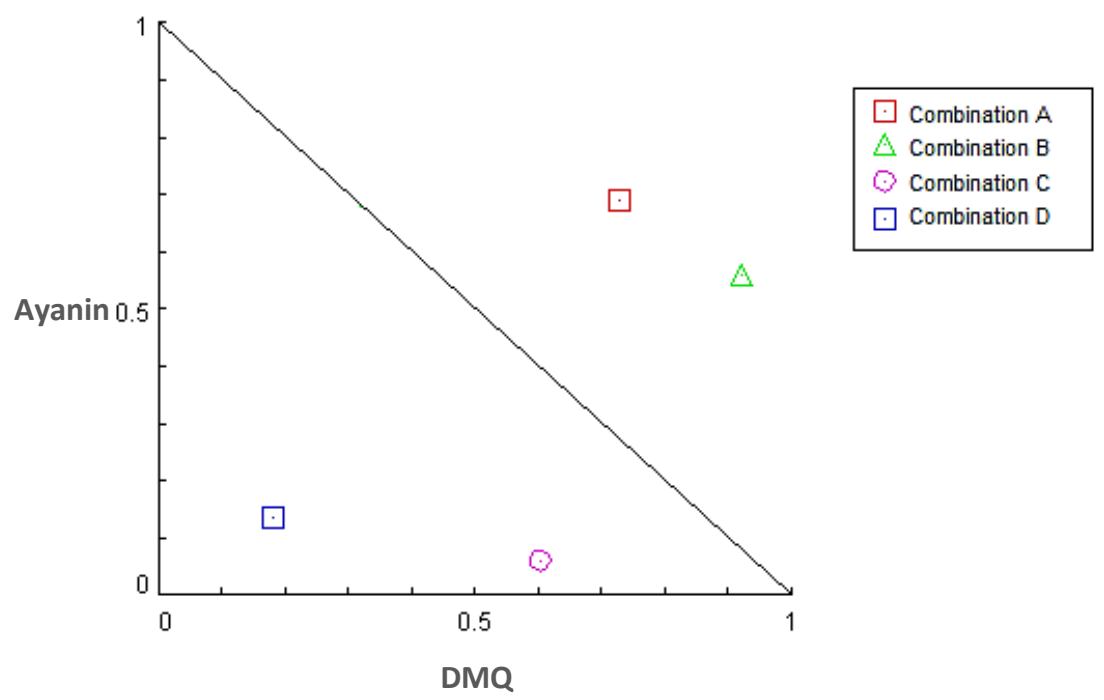

Figure 8. Isobologram generated by CompuSyn applying the Loewe model for the combinations of ayanin and DMQ. Combination data points that fall below the line is synergistic, above the line is antagonistic and on the line is additive. The ratio between effect of the single flavonoid dose [(D)1] and effect of the same flavonoid dose when tested in combination [(Dx)1] is reported on axes Ayanin and DMQ. Combination A: Ayanin (0.01-0.03 $\mu \mathrm{M})+$ DMQ $(0.03 \mu \mathrm{M})$; Combination B: Ayanin $(0.01-0.03 \mu \mathrm{M})+\mathrm{DMQ}(0.1 \mu \mathrm{M})$; Combination C: Ayanin (30-60 $\mu \mathrm{M})+$ DMQ $(3 \mu \mathrm{M})$; Combination D: Ayanin $(30-60 \mu \mathrm{M})+\mathrm{DMQ}(30 \mu \mathrm{M})$.

The combination index values $(\mathrm{Cl})$, and the percentage of synergism were obtained for each combination of ayanin plus DMO evaluated; those with more representative values and $p<0.05$ are shown in Table 1. Combinations with a $\mathrm{Cl}>1$ indicate that there is antagonism, and a $\mathrm{Cl}<1$ shows that the interaction is synergistic. Respect of the percentage of synergism from Combenefit, a score above $0 \%$ indicates synergism, and a score below $0 \%$ indicates antagonism.

Table 1. Combination index $(\mathrm{Cl})$ values and percentage of synergism of synergism scores of ayanin $(0.01-0.1 \mu \mathrm{M})$ and DMO (0.01-0.3 $\mu \mathrm{M})$ combinations in aortic rings pre-contracted with phenylephrine. ${ }^{* * *} \mathrm{p}<0.001,{ }^{* *} \mathrm{p}<0.01,{ }^{*} \mathrm{p}<0.05$.

\begin{tabular}{ccccc}
\hline $\begin{array}{c}\text { Ayanin } \\
{[\mu \mathrm{M}]}\end{array}$ & $\begin{array}{c}\mathrm{DMQ} \\
{[\mu \mathrm{M}]}\end{array}$ & $\begin{array}{c}\text { Cl value } \\
\text { (Compusyn) }\end{array}$ & $\begin{array}{c}\text { \% Synergism } \\
\text { (Combenefit) }\end{array}$ & $\mathbf{p < 0 , 0 5}$ \\
\hline 0.01 & 0.03 & 90.80 & $-12 \pm 1$ & $\star \star \star$ \\
0.01 & 0.1 & 119.02 & $-15 \pm 1$ & $\star \star \star$ \\
0.03 & 0.03 & 6.13 & $-8 \pm 2$ & $*$ \\
0.03 & 0.1 & 15.23 & $12 \pm 1$ & $\star \star$ \\
30 & 3 & 0.12 & $20 \pm 3$ & $\star \star$ \\
30 & 30 & 0.18 & $12 \pm 1$ & $\star \star$ \\
60 & 3 & 0.04 & $27 \pm 1$ & $\star \star \star$ \\
60 & 30 & 0.00 & $21 \pm 2$ & $\star \star$ \\
\hline
\end{tabular}

\section{DISCUSSION}

This research was focused on assessing vascular interactions between ayanin and 3,7-Di-Omethylquercetin (DMQ), the two main bioactive flavonoids from Croton schiedeanus, and synergism between them, which could help explain the vasodilator and antihypertensive effects seen with the whole extract in experimental models in rats $(18,25)$. As a result, this research was focused on identifying possible interactions between these two metabolites, which have not previously been studied.

Evaluating the interaction between ayanin and DMQ, a dual effect can be seen depending on the concentration applied, as follows: lower DMQ concentrations decrease the relaxant response of ayanin, whereas higher concentrations increase it (Fig. 2 and Fig. 3). Hence, combining ayanin in the range of $30-60 \mu \mathrm{M}$ and $\mathrm{DMO}$ in the range of 3-30 $\mu \mathrm{M}$ generates a vascular relaxant response $\left(E_{\max }\right)$ greater than that obtained using single flavonoids, and greater than that obtained using the whole ethanolic extract (Fig. 4). Besides, this increase is synergistic, as could be assessed by the combination index $(\mathrm{Cl})$ and percentage score values and the isobologram obtained (Fig. 6, Fig. 7, Fig. 8, and Table 1). Therefore, appropriate combinations of ayanin and DMO could be more beneficial than the whole extract for vasodilator purposes. 
Certainly, the efficacy or relaxation $\left(E_{\max }\right)$ obtained using DMO is higher than that obtained employing ayanin. In turn, the ayanin relaxation is higher than the obtained using the whole extract, supporting that these flavonoids play a key role in the response generated by Croton schiedeanus. However, and more interestingly, the combined use of DMQ and ayanin at higher concentrations is even more efficient (Fig. 4).

According to this research, the $\mathrm{EC}_{50}$ of ayanin, $\mathrm{DMQ}$, and whole extract would be considered higher than the previously reported $(18,25,38)$. However, note that the relaxation percentages obtained using all treatments were normalized to maximal relaxation attained with ayanin and DMO combined at a high concentration (Fig. 4). The basal tension applied was $2 \mathrm{~g}$, the maximal relaxant effect was even lower than this value. The highest value of $\mathrm{E}_{\max }$ was obtained with the combination of ayanin plus DMQ at $3 \times 10^{-5} \mathrm{M}$ $\left(3 \times 10^{-6} \mathrm{~g} / \mathrm{mL}\right)$ and was about $170.25 \%$, which corresponds to $100 \%$ of the response applying normalization.

CompuSyn and Combenefit are two of the most commonly used open platforms to assess combined drug interactions by applying mass action law as one of their fundamentals $(36,37)$. Parameters such as the combination index $(\mathrm{Cl})$ in CompuSyn and percentage of scores in Combenefit guide the researcher to identify synergism, additivity, or antagonism between two drugs. The isobologram in CompuSyn and tridimensional graphs in Combenefit ease to identify points of drug combinations that behave in one of such interactions. Thus, a $\mathrm{Cl}<1$ in CompuSyn and a score above $0 \%$ in Combenefit led to identifying points of synergism. That is the case for ayanin combined with DMO in the range of 30-60 and 3-30 $\mu \mathrm{M}$, respectively (Fig. 6, Fig. 7, Fig. 8, Table 1), supporting the viewpoint that appropriate combinations of those flavonoids could be advantageous over the whole extract when the vasodilator response is the target.

Besides, concerning the individual efficacy of the evaluated flavonoids, it was found that DMO exerts greater relaxation than ayanin; therefore, its efficacy is greater. Similarly, the values of $\mathrm{EC}_{50}$ indicates that the potency of DMO is greater than that obtained using ayanin. Previous studies reported that the $\mathrm{EC}_{50}$ in aortic rings pre-contracted with phenylephrine was $4.9 \times 10^{-6} \mathrm{M}$ for DMO (25) and $5.4 \times 10^{-5} \mathrm{M}$ for ayanin (39). Nevertheless, in this research, $\mathrm{EC}_{50}$ values of $1.3 \times 10^{-6} \mathrm{M}$ for $\mathrm{DMO}$ and $3.9 \times 10^{-7} \mathrm{M}$ for ayanin were found, and they are smaller than those reported in the literature.
Second, to find any interaction, different combinations of flavonoids were studied, and it was evident that a dual effect exists in terms of concentration - dependent. Here, the lowest concentrations of DMQ cause the response of ayanin to be decreased. In contrast, the response of ayanin was increased significantly when the highest concentrations of DMQ were added to the bath.

If this approach can be translated to an in vivo scenario, the combined use of ayanin and DMQ could be an interesting alternative, with better antihypertensive control expected; however, more research with those metabolites combined in in vivo experiments is needed to support this proposition.

Intended to detect pharmacological interactions, either synergistic, antagonistic, or additivity, when using any of the flavonoids under study and at different concentrations, we analyzed data using the Loewe model, with open code platforms such as Combenefit and CompuSyn $(37,38)$.

Figures 6, 7, and 8 show a dual effect: increase and decrease in the relaxing effect, depending on the flavonoid concentration. The surface map, where the different concentrations of ayanin and DMQ are correlated simultaneously, and the percentage of synergism between these two compounds is observed, showing concentrations that generate synergism in blue, moving from lighter to darker. In contrast, the concentrations that resulted in antagonism are shown in yellow and orange. It is important to emphasize that each point represent different combinations of ayanin plus DMQ; those with a position above zero (respect to the percentage synergy axis) indicate synergism, while combinations showing antagonism are below zero. Similarly, if the points are located on the zero of synergy percentage, there is additivity. According to the location of the points concerning the zero percent of synergism, it is possible to deduce that when higher concentrations of DMQ were evaluated in the presence of higher concentrations of ayanin, the points are located above zero. This means that the combinations with the highest concentrations of flavonoids evaluated exert synergism, yielding a percentage of this interaction from $12 \pm 1 \%$ to $27 \pm$ $1 \%$. However, the greater the concentration decrease of each compound in the combinations, the greater the reduction in the synergism percentage, yielding an antagonistic effect, with values below zero for synergism percentages, such as $-8 \pm 2 \%$, and even lower values with a $p$-value below 0.05 . That 
percentage accounts for the relationship between the type of interaction and the concentration.

Alternatively, the CompuSyn platform allowed an isobologram to be created to identify the type of interaction. It is important to consider that points located under the slope indicate a synergistic combination. Points located above the slope indicate an antagonistic combination. Finally, points on the slope show additive combinations. Therefore, it is possible to infer that some combinations with lower flavonoid concentrations tend to be antagonistic. The points representing these combinations ( $A$ and $\mathrm{B}$; figure 8) are located above the slope. Likewise, their $\mathrm{Cl}$ values are greater than one. However, other points are not antagonistic, with results under the slope showing synergism ( $C$ and $D$; figure 8 ) and $\mathrm{Cl}$ values below one (Table 1).

The dual effect found in the results can be correlated with certain concentrations of ayanin and DMQ added at the same time in the organ bath. This is interesting, considering that compounds exist in the same plant and extract with similar chemical structures and different effects if used together at different concentrations.

Regarding the vascular response, dual effects have been noted with flavonoid compounds. For example, kaempferol and myricetin stimulate voltage-gated calcium channels $\left(\mathrm{Ca}_{v} 1.2\right.$ channels), which mediate the vasodilator response. In contrast, galangin and naringenin inhibited the calcium channels, with effects related to the double bond between $\mathrm{C} 2$ and $\mathrm{C} 3$ in the flavonoid structure, and the distribution of $\mathrm{OH}$ groups on the flavonoid ring (40).

Another dual effect has been observed in the case of some flavonoids. It has been found that several biological activities can be manifested, one of which is anxiolytic activities; however, preparations of fresh parts of Petiveria alliacea, which are rich in flavonoids, can result in opposite effects on anxiety in mice (41).

In contrast, flavonoids, in general, can inhibit several enzymes in vitro (28); some of their mechanisms of action in the cell membrane are associated with the transport of ions, such as $\mathrm{Ca}^{2+} / \mathrm{Mg}^{2+}$ by ATPase, $\mathrm{Na}^{+} /$ $\mathrm{K}^{+}$by ATPase, and mitochondrial ATPase, as well as the inhibition of cAMP or cGMP-phosphodiesterase and protein kinase. However, in a study conducted with quercetin in an isolated organ bath with the portal vein of Wistar rats, a dual effect of the vasorelaxation and contraction was evidenced. The results demonstrated that the inhibitory effect of quercetin on the portal vein is related to an increase in basal tone and contractile frequencies. However, this contraction is followed by a pronounced and lasting secondary relaxation (42).

The opposite effect of flavonoid compounds has also been observed on the antioxidant activity of several of these compounds, including myricetin and quercetin. This fact could be related to hydrogen bonds between these compounds, decreasing hydroxyl groups' availability to elicit their radical scavenging activity (43). Besides, dual effects between flavonoid compounds, depending on the concentration applied, have also been described, such as hyperglycemia induced by $\alpha$-glucosidase in the presence of myricetin and apigenin (44).

In another previous research, the antioxidant activity of different mixtures of catechins present in green tea was evaluated. These compounds were combined in pairs with their respective stereoisomers. The catechins consist of a subgroup of flavonoids known as flavan-3-ols. Some of them result in synergism, others in antagonism and additivity, while others still show no interaction. In addition, some compounds even showed the same percentage of synergism as antagonism (45). Another example was the interactions between the flavonoids quercetin, epicatechin, rutin, and resveratrol in red grape, resulting in synergism and antagonism, which were concentration-dependent, and the antioxidant activity was assessed by the DPPH and peroxynitrite tests $(46,47)$.

Previous studies have described some examples, which show that dual effects exist when some flavonoids are used in combination. According to the results, a dual effect was shown when the relaxation induced by ayanin with variable concentrations of DMQ was evaluated. The result was an antagonistic effect at low concentrations and synergistic at high concentrations. However, as far as the bibliographic review of this research allows, it is possible to say that this duality has not been explicitly documented in these flavonoids.

Concerning synergism, even though the exact definition of pharmacological synergy is still under debate, it is possible to explain it as a positive interaction when a pharmacological effect is reached. Alternatively, the concept of additivity is different, as this is a measure of the response of a combination of drugs; for example, a combination of compounds may be highly synergistic but at the same time insufficient to achieve the expected pharmacological effect. This means 
that if a combination exerts a high effect, it does not necessarily imply that it will have a synergistic interaction (37). For this study, it was possible to consider that the positive interaction found was more closely related to the definition of synergism than to the definition of additivity, which considers that there are positive interactions when the efficacy of the compounds evaluated is equal. Potency is minimally different between the compounds (48), which were not reflected in the present results because of the differences in the $\mathrm{E}_{\max }$ and $\mathrm{EC}_{50}$ between ayanin and DMO.

Synergistic effects among flavonoid compounds or between flavonoids and chemical drug entities have been described in other fields of biological research; for example, between vicenin-2 and docetaxel for prostate cancer (49), between apigenin and ceftazidime against resistant Enterobacter (50), between catechin, quercetin and epigallocatechin gallate with fluconazole against resistant candida (51), between tangeretin and atorvastatin for colon cancer (52), between hesperidin and diazepam for anxiolysis (53), and between quercetin, gallic acid, and rutin for antioxidant effects (54).

Alternatively, the antioxidant effect is related to synergistic interactions; for example, between delta-tocopherol, epicatechin, and epigallocatechin gallate in vitro, or between quercetin and catechin that act together to inhibit platelet adhesion and aggregation induced by collagen (55). Also, quercetin and kaempferol work together to decrease the proliferation of $\mathrm{CaCo}-2$ and HuTu-80, and PMC42 carcinoma cells. This effect is attributed to the blockage of the cell cycle after protein synthesis before starting the mitotic phase (56). Simultaneously, flavonoids from Annona muricata have shown anti-proliferative activity in mice with prostate tumor xenografts (57). All this information shows the interest to use flavonoids in combination to reach synergistic effects.

In order to approach the possible mechanism involved in the interaction between flavonoids, the combination that exerted the greatest potency and efficacy (ayanin plus DMO $3 \times 10^{-5} \mathrm{M}$ ) was studied in the presence of L-NAME and methylene blue. An increase in the nitric oxide/GMPc pathway activity has been described as a key mechanism related to the vasodilator response induced by ayanin $(39,58)$. However, when ayanin and DMO were combined, the inhibition of that route with L-NAME and methylene blue, although decreased the response, did not prevent vascular relaxation (Fig. 5), confirming that there was an interaction between these flavonoids. Nevertheless, the results also suggested that another mechanism of action should be implicated in the interaction between ayanin and DMQ, which adds support to the idea that a synergistic effect is established between those flavonoids through more than one mechanism, where calcium channel inhibition could be implicated (39).

Other different ways could be involved that were endothelium-dependent, such as those mediated by prostacyclin $\left(\mathrm{PGI}_{2}\right)$, which consists of a vasodilator endothelium-derived prostaglandin (cyclooxygenase dependent) (59), like endotheliumderived hyperpolarizing factor (EDHF) (60). In previous assays, it was shown that endothelial vasorelaxant factors derived from cyclooxygenase participate in the relaxant effect of ayanin (39). However, endothelium-derived factors may not be the only factors associated with the synergism between ayanin and DMQ. It has been found that the presence of endothelium was unessential to exert a vasorelaxant effect by $\mathrm{DMO}$ in vitro because the response was reduced but not abolished when assays were performed on aorta rings without endothelium $(25,32)$.

Concerning the possible endothelium-independent mechanisms associated with the synergism between the main metabolites from Croton schiedeanus, it is also possible to consider mechanisms that have demonstrated to involve non-adrenergic and non-cholinergic nerves along with calcitonin generelated peptide (CGRP). This potent vasodilator neuropeptide acts as a neurotransmitter to regulate vascular tone along with adrenergic nerves in the rat mesenteric artery (61).

Another endothelium-independent mechanism could be related to the vasodilator effect exerted by ceramide, which stimulates the ceramide-activated protein kinase and ceramide-activated protein phosphatase and inhibits protein kinase C (PKC), which is important to mediate the contractile effects of G-protein coupled receptors to norepinephrine and angiotensin II $(62,63)$.

The vasorelaxant effect and the contribution of flavonoids to the improvement of cardiovascular disease have been mainly associated with their antioxidant properties. However, it is compelling to be aware that these compounds can act through other mechanisms, which involve different pathways.

In conclusion, ayanin and DMO elicited a dual vascular response in isolated Wistar aortic rings, 
which depended on the assayed concentration: inhibition at a lower concentration range and synergism at a higher. The combined was only partially dependent on the NO/cGMP pathway. Appropriate combinations of those flavonoids could improve the response seen with the entire Croton schiedeanus extract. Further research is needed to verify the interaction between those flavonoids in in vivo experiments.

\section{CONCLUSION}

The results obtained in this research suggested a concentration-dependent dual effect between the main flavonoids isolated from Croton schiedeanus. In some of the evaluated combinations of compounds, the synergism was corroborated when L-NAME and methylene blue did not reverse the vasorelaxant effect when added to the organ bath, combined with ayanin plus DMO that exerted the highest synergism percentage. That interaction could involve another mechanism that was not associated with the NO/cGMP pathway.

Synergy is considered an advantage of the chemical complexity of the extracts obtained from plants when the effect and/or the potency of a combination of compounds is greater than each compound separately, exerting a cumulative effect (28). An improvement in the vasorelaxant effect of ayanin in the presence of specific concentrations of DMQ isolated from Croton schiedeanus is seen in this study.

Currently, there is increasing interest in the study of synergistic interactions in phytotherapy, considering ways to improve the therapeutic effect, reducing adverse effects, including the combination of several compounds.

To conclude, the identification and determination of interactions was achieved between the main flavonoids of Croton schiedeanus in the organ bath. Concerning synergy identified, it could be possible to purpose the bases of this study for an eventual phytotherapeutic for vasodilator purposes.

Conflict of interest. None of the authors have any conflicts of interest related to this study.

\section{REFERENCES}

1. Kjeldsen SE. Hypertension and cardiovascular risk: General aspects. Pharmacol Res [Internet]. 2018 Mar;129:95-9. Available from: https://pubmed.ncbi.nlm.nih.gov/29127059/\#: :text=Hype rtension is the strongest or,cerebral stroke and renal failure. DOI: https://doi.org/10.1016/j.phrs.2017.11.003
2. Ordunez P, Martinez R, Niebylski ML, Campbell NR. Hypertension prevention and control in Latin America and the Caribbean. J Clin Hypertens [Internet]. 2017;17(7):499-502. Available from: https:// onlinelibrary.wiley.com/doi/pdfdirect/10.1111/jch.12518. DOI: https://doi.org/10.1111/jch.12518

3. Gradman AH, Basile JN, Carter BL, Bakris GL. Combination therapy in hypertension. J Am Soc Hypertens [Internet]. 2010;4(2):90-8. Available from: https://www.ncbi.nlm.nih.gov/pmc/articles/ PMC5992964/. DOI: https://doi.org/10.7573/dic.212531

4. Hardman J., \& Goodman LL. Goodman \& Gilman. Las bases farmacológicas de la terapéutica. 12th ed. McGraw-Hill; 2012. 2035 p. ISBN: 978-1-4562-6356-0

5. Ministerio de Salud y Protección Social. Día mundial de la hipertensión arterial Colombia - mayo 17 de 2017 [Internet]. Bogotá; 2017. p. 1-11. Available from: ish-world.com/events/e/ World-Hypertension-Day-2016/

6. Galarza CR. Adherencia e intensificación del tratamiento. In: Hipertensión arterial, epidemiología, fisiología, fiosiopatología, diagnóstico y terapéutica [Internet]. Buenos Aires, Argentina: Sociedad Argentina de Hipertensión Arteria SAHA; 2017. p. 475-8. Available from: https://www.saha.org.ar/pdf/libro/Cap.100.pdf. ISBN: 9789505554157

7. Nerenberg KA, Zarnke KB, Leung AA, Dasgupta K, Butalia S, Mcbrien K, et al. Hypertension Canada's 2018 guidelines for diagnosis, risk assessment, prevention, and treatment of hypertension in adults and children. Can J Cardiol [Internet]. 2018;34(5):506-25. Available from: https://pubmed.ncbi.nlm.nih. gov/29731013/. DOI: https://doi.org/10.1016/j.cjca.2018.02.022

8. Ulrich-Merzenich GS. Combination screening of synthetic drugs and plant derived natural products - Potential and challenges for drug development. Synerg Res [Internet]. 2014;1(1):59-69. DOI: https://doi.org/10.1016/j.synres.2014.07.011

9. Guerrero MF, Puebla P, Carrón R, Martín ML, Arteaga L, Román LS. Assessment of the antihypertensive and vasodilator effects of ethanolic extracts of some Colombian medicinal plants. $J$ Ethnopharmacol [Internet]. 2002 Apr [cited 2018 Dec 1];80(1):3742. DOI: https://doi.org/10.1016/S0378-8741(01)00420-2

10. Kumar S, Pandey AK. Chemistry and biological activities of flavonoids: an overview. Sci World J [Internet]. 2013 [cited 2018 Dec 1]; DOI: https://doi.org/10.1155/2013/162750

11. Falcone Ferreira ML, Rius $S$, Casati P. Flavonoids: biosynthesis, biological functions, and biotechnological applications. Front Plant Sci [Internet]. 2012;3:222. DOI: https://doi.org/10.3389/ fpls.2012.00222

12. Macready AL, George TW, Chong MF, Alimbetov DS, Jin Y, Vidal $A$, et al. Flavonoid-rich fruit and vegetables improve microvascular reactivity and inflammatory status in men at risk of cardiovascular disease - FLAVURS: a randomized controlled trial. Am J Clin Nutr [Internet]. 2014;99(3):479-89. DOI: https://doi.org/10.3945/ ajcn.113.074237

13. Rees A, Dodd G, Spencer J. The effects of flavonoids on cardiovascular health: a review of human intervention trials and implications for cerebrovascular function. Nutrients [Internet]. 2018 [cited 2018 Dec 15];10(12):1852. DOI: https://doi.org/10.3390/ nu10121852

14. Bjørklund G, Dadar M, Chirumbolo S, Lysiuk R. Flavonoids as detoxifying and pro-survival agents: What's new? Food Chem Toxicol [Internet]. 2017;110:240-50.DOI: https://doi.org/10.1016/j. fct.2017.10.039

15. Hollman PC. Absorption, Bioavailability, and Metabolism of Flavonoids. Am J Clin Nutr [Internet]. 2004 Jan 1 [cited 2018 Dec 17];42(sup1):74-83. DOl: https://doi. org/10.3109/13880200490893492 
16. Maciel M, Cortez JKPC, Gomes FES. O gênero Croton e aspectos relevantes de diterpenos clerodanos [Internet]. Universidade Federal do Rio Grande do Norte. 2006. Available from: https:// www.arca.fiocruz.br/handle/icict/18405

17. Salatino A, Salatino MLF, Negri G. Traditional uses, chemistry and pharmacology of Croton species (Euphorbiaceae). J Braz Chem Soc [Internet]. 2007 [cited 2018 Dec 1];18(1):11-33. DOI: https:// doi.org/10.1590/S0103-50532007000100002

18. Torres MC, Ibañez PP, Pabón MG. Vasodilatación inducida por Croton schiedeanus Schlecht vinculada con la ruta metabólica de guanilato ciclasa. Rev Colomb Ciencias Químico-Farmacéuticas [Internet]. 2012;41(1):36-49. DOI: https://doi.org/10.15446/ rcciquifa

19. Escobar Ocampo MC, Niños Cruz JÁ, Ramírez Marcial N, Yépez Pacheco C. Diagnóstico participativo del uso, demanda y abastecimiento de leña en una comunidad zoque del centro de Chiapas, México. Ra Ximhai [Internet]. 2009;5:201-23. DOI: https:// doi.org/10.35197/rx.05.02.2009.06.me

20. Madrigal Alfaro LÁ. Determinación de árboles asociados a bosques ribereños en tres sub-cuencas del río Grande de Térraba; Río Volcán, Quebrada Dibujada y Quebrada Fría [Internet]. Universidad de Costa Rica; 2019. Available from: http://repositorio. sibdi.ucr.ac.cr:8080/jspui/handle/123456789/10200. ISBN: 9788578110796

21. Martínez I, Serracín YL. Flora asociada a humedales en Cuesta de Piedra, Chiriquí [Internet]. 1st ed. David, Panamá 2015. 176 p. Available from: https://jadimike.unachi.ac.pa/ handle/123456789/47

22. Páez MT, Rodríguez DC, López DF, Castañeda JA, Buitrago DM, Cuca LE, et al. Croton schiedeanus Schltd prevents experimental hypertension in rats induced by nitric oxide deficit. Brazilian J Pharm Sci [Internet]. 2013;49(4):865-71. DOI: https://doi. org/10.1590/S1984-82502013000400027

23. Guerrero MF, Puebla P, Carrón R, Martın ML, San Román $L$. Vasorelaxant effect of new neo-clerodane diterpenoids isolated from Croton schiedeanus. J Ethnopharmacol [Internet]. 2004;94(1):185-9. DOI: https://doi.org/10.1016/j.jep.2004.05.018

24. Duarte J, Pérez-Palencia R, Vargas F, Angeles Ocete M, PérezVizcano F, Zarzuelo A, et al. Antihypertensive effects of the flavonoid quercetin in spontaneously hypertensive rats. $\mathrm{Br}$ J Pharmacol [Internet]. 2001;133(1):117-24. DOI: https://doi. org/10.1038/sj.bjp.0704064

25. Correa Hernández $S X$, Puebla Ibánez $P$, de la Calle RC, Martín Calvo ML, del Barrio LSR, Pabón MFG. Perfil vasodilatador de compuestos flavonoides y fenilbutanoides aislados de Croton schiedeanus Schlecht. Rev Fac Med [Internet]. 2008;56(4):291-301. DOI: https://doi.org/10.15446/revfacmed

26. Tallarida RJ. Quantitative methods for assessing drug synergism. Genes Cancer [Internet]. 2011;2(11):1003-8. DOI: https://doi org/10.1177/1947601912440575

27. Yang Y, Zhang Z, Li S, Ye X, Li X, He K. Synergy effects of herb extracts: Pharmacokinetics and pharmacodynamic basis. Fitoterapia [Internet]. 2014;92:133-47. DOI: https://doi. org/10.1016/j.fitote.2013.10.010

28. Mills S, Bone K. Principles of herbal pharmacology. In: Principles and Practice of Phytotherapy: Modern Herbal Medicine [Internet]. Churchill Livingstone: Elsevier; 2012. p. 45-82. Available from: https://www.elsevier.com/books/principles-and-practice-ofphytotherapy/9780443069925. ISBN: 9780443069925

29. Loewe S. Die quantitativen Probleme der Pharmakologie. Ergebnisse der Physiol [Internet]. 1928;27(1):47-187. Available from: https://link.springer.com/article/10.1007/BF02322290
30. Loewe $\mathrm{S}$. The problem of synergism and antagonism of combined drugs. Arzneimittelforschung [Internet]. 1953;3:285-290. Available from: https://pubmed.ncbi.nlm.nih.gov/13081480/. PMID: 13081480

31. Chou TC. Frequently asked questions in drug combinations and the mass-action law-based answers. Synergy [Internet]. 2014;1(1):3-21. DOI: https://doi.org/10.1016/j.synres.2014.07.003

32. Guerrero MF, Puebla P, Carrón R, Martin ML, Román LS. Quercetin 3, 7-dimethyl ether: a vasorelaxant flavonoid isolated from Croton schiedeanus Schlecht. Pharm Pharmacol [Internet]. 2002;54(10):1373-8. DOI: https://doi. org/10.1211/002235702760345455

33. Wollenweber E, Smith DM, Reeves T. Flavonoid patterns and chemical races in the California Cloak-fern, Notholaena californica. Stud Org Chem [Internet]. 1981;11:221. DOI: https:// doi.org/10.1177/1934578X0600101101

34. Guerrero MF. Guía para la evaluación farmacológica de agentes vasodilatadores en Baño de Órgano Aislado. Primera Ed. Universidad Nacional de Colombia, editor. Universidad Nacional de Colombia; 2016. 52 p. ISBN: 9789587759464

35. Chou TC. Theoretical basis, experimental design, and computerized simulation of synergism and antagonism in drug combination studies. Pharmacol Rev [Internet]. 2006;58(3):621-81. DOI: https:// doi.org/10.1124/pr.58.3.10

36. Di Veroli GY, Fornari C, Wang D, Mollard S, Bramhall JL, Richards FM, et al. Combenefit: an interactive platform for the analysis and visualization of drug combinations. Bioinformatics [Internet]. 2016;32(18):2866-8. DOI: https://doi.org/10.1093/bioinformatics/ btw230

37. Tang, J., Wennerberg, K., \& Aittokallio T. What is synergy? The Saariselkä agreement revisited. Front Pharmacol [Internet]. 2015;6:1-5. Available from: DOI: https://doi.org/10.3389/ fphar.2015.00181

38. Chou TC. Drug combination studies and their synergy quantification using the Chou-Talalay Method. Cancer Res [Internet]. 2010;70(2):440-6. DOI: https://doi.org/10.1158/00085472.CAN-09-1947

39. Carrón R, Sanz E, Puebla P, Martín ML, San Román L, Guerrero MF. Mechanisms of relaxation induced by flavonoid ayanin in isolated aorta rings from Wistar rats. Colomb Med [Internet]. 2010;41(1):10-6. Available from: http://www.scielo.org.co/scielo. php?script=sci_arttext\&pid=S1657-95342010000100002.

40. Saponara S, Carosati E, Mugnai P, Sgaragli G, Fusi F. The flavonoid scaffold as a template for the design of modulators of the vascular Cav 1.2 channels. Br J Pharmacol [Internet]. 2011;164(6):1684-97. DOI: https://doi.org/10.1111/j.1476-5381.2011.01476.x

41. Blainski A., Piccolo V. K., Mello J. C. P., \& de Oliveira RM. Dual effects of crude extracts obtained from Petiveria alliacea L. (Phytolaccaceae) on experimental anxiety in mice. J Ethnopharmacol [Internet]. 2010;128:541-4. DOI: https://doi. org/10.1016/j.jep.2010.01.012

42. Chiwororo WDH, Ojewole JAO. Dual effect of quercetin on rat isolated portal vein smooth muscle contractility. Cardiovasc J Afr [Internet]. 2010;21(3):132-6. Available from: https://www.ncbi.nlm. nih.gov/pmc/articles/PMC3721696/. PMID: 20532450

43. Hidalgo M, Sánchez-Moreno C, de Pascual-Teresa S. Flavonoidflavonoid interaction and its effect on their antioxidant activity. Food Chem [Internet]. 2010;121:691-6. DOI: https://doi. org/10.1016/j.foodchem.2009.12.097

44. Zeng L, Zhang G, Lin S, Gong D. Inhibitory mechanism of apigenin on $\alpha$-glucosidase and synergy analysis of flavonoids. J Agric Food Chem [Internet]. 2016;64(37):1-45. DOI: https://doi.org/10.1021/ acs.jafc. $6 \mathrm{~b} 02314$ 
45. Colon M, Nerín C. Synergistic, antagonistic and additive interactions of green tea polyphenols. Eur Food Res Technol [Internet]. 2016;242(2):211-20. DOI: https://doi.org/10.1007/ s00217-015-2532-9

46. Iacopini P, Baldi M, Storchi P, Sebastiani L. Catechin, epicatechin, quercetin, rutin and resveratrol in red grape: Content, in vitro antioxidant activity and interactions. J Food Compos Anal [Internet]. 2008;21(8):589-98. DOI: https://doi.org/10.1016/j. jfca.2008.03.011.

47. Li D, Sun-Waterhouse D, Wang Y, Qiao X, Chen Y, Li F. Interactions of some common flavonoid antioxidants. Encycl Food Chem [Internet]. 2019;644-9. DOI: https://doi.org/10.1016/B978-0-08100596-5.21509-6.

48. Tallarida RJ. Drug Synergism: Its detection and applications. J Pharmacol Exp Ther [Internet]. 2001;298(3):865-72. Available from: https://pubmed.ncbi.nlm.nih.gov/11504778/. PMID: 11504778

49. Nagaprashantha LD, Vatsyayan R, Singhal J, Fast S, Roby R, Awasthi $S$, et al. Anti-cancer effects of novel flavonoid vicenin-2 as a single agent and in synergistic combination with docetaxel in prostate cancer. Biochem Pharmacol [Internet]. 2011;82(9):1100-9. DOI: https://doi.org/10.1016/j.bcp.2011.07.078

50. Eumkeb G, Chukrathok S. Synergistic activity and mechanism of action of ceftazidime and apigenin combination against ceftazidime-resistant Enterobacter cloacae. Phytomedicine [Internet]. 2013;20(3-4):262-9. DOI: https://doi.org/10.1016/j. phymed.2012.10.008

51. Da Silva CR, De Andrade Neto JB, De Sousa Campos R, Figueiredo NS, Sampaio LS, Magalhães HIF, et al. Synergistic effect of the flavonoid catechin, quercetin, or epigallocatechin gallate with fluconazole induces apoptosis in Candida tropicalis resistant to fluconazole. Antimicrob Agents Chemother [Internet]. 2014;58(3):1468-78. DOI: https://doi.org/10.1128/AAC.00651-13

52. Bao H, Zheng N, Li Z, Zhi Y. Synergistic effect of tangeretin and atorvastatin for colon cancer combination therapy: Targeted delivery of these dual drugs using RGD peptide decorated nanocarriers. Drug Des Devel Ther [Internet]. 2020;14:3057-68. DOI: https://doi.org/10.2147/DDDT.S256636

53. Fernández SP, Wasowski C, Loscalzo LM, Granger RE, Johnston GAR, Paladini AC, et al. Central nervous system depressant action of flavonoid glycosides. Eur J Pharmacol [Internet]. 2006;539(3):168-76. DOI: https://doi.org/10.2147/DDDT. S25663610.1016/j.ejphar.2006.04.004

54. Hajimehdipoor H, Shahrestani R, Shekarchi M. Investigating the synergistic antioxidant effects of some flavonoid and phenolic compounds. J Pharmacogn [Internet]. 2014;43(4):416-22. Available from: http://www.rjpharmacognosy.ir/article_5776.html

55. Frank J, Budek A, Lundh T, Parker RS, Swanson JE, Lourenço $\mathrm{CF}$, et al. Dietary flavonoids with a catechol structure increase $\alpha$-tocopherol in rats and protect the vitamin from oxidation in vitro. J Lipid Res [Internet]. 2006;47(12):2718-25. DOI: https://doi. org/10.1194/jlr.m600291-jlr200

56. Ackland ML, Van De Waarsenburg S, Jones R. Synergistic antiproliferation action of the flavonols quercetin and kaempferol in cultured human cancer cell lines. In Vivo (Brooklyn) [Internet]. 2005;19(1):69-76. Available from: https://pubmed.ncbi.nlm.nih. gov/15796157/. PMID: 15796157

57. Yang C, Gundala SR, Mukkavilli R, Vangala S, Reid MD, Aneja $R$. Synergistic interactions among flavonoids and acetogenins in Graviola (Annona muricata) leaves confer protection against prostate cancer. Carcinogenesis [Internet]. 2015;36(6):656-65. DOI: https://doi.org/10.1093/carcin/bgv046

58. Guerrero MF, Puebla P, Reguero MT, Arteaga L. Inhibitory Effect of $N(G)$-Nitro-L-arginine Methyl Ester on the Anti-Adrenergic Response Elicited by Ayanin in the Pithed Rat. Planta Med [Internet]. 2002;68(4):322-5. DOI: https://doi.org/10.1055/s-2002-26755

59. Durand MJ, Gutterman DD. Diversity in mechanisms of endothelium-dependent vasodilation in health and disease. Microcirculation [Internet]. 2013;20(3):239-47. DOI: https://doi. org/10.1111/micc.12040

60. Quillon A, Fromy B, Debret R. Endothelium microenvironment sensing leading to nitric oxide mediated vasodilation: A review of nervous and biomechanical signals. Nitric Oxide - Biol Chem [Internet]. 2015;45:20-6. DOI: https://doi.org/10.1016/j. niox.2015.01.006

61. Iwatani $Y$, Kosugi K, Isobe-Oku S, Atagi S, Kitamura Y, Kawasaki $\mathrm{H}$. Endothelium removal augments endothelium-independent vasodilatation in rat mesenteric vascular bed. $\mathrm{Br} \mathrm{J}$ Pharmacol [Internet]. 2008;154(1):32-40. DOI: https://doi.org/10.1038/ bjp. 2008.72

62. Johns DG, Webb RC, Abdullah HI, Pedraza PL, Hao S, Rodland $K D$, et al. TNF- $\alpha$-induced endothelium-independent vasodilation: a role for phospholipase A2-dependent ceramide signaling. J Physiol [Internet]. 1998;275:1592-8. DOI: https://doi.org/10.1152/ ajpheart.1998.275.5.H1592

63. Johns DG, Osborn H, Webb RC. Ceramide: A novel cell signaling mechanism for vasodilation. Biochem Biophys Res Commun [Internet]. 1997;237(1):95-7. DOI: https://doi.org/10.1152/ ajpheart.1998.275.5.H1592 